\title{
Histopathological Evaluation of Pterygium Patients with Type 2 Diabetes Mellitus
}

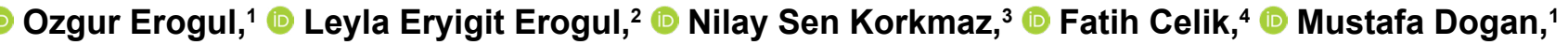 \\ Hamidu Hamisi Gobeka²
}

1Department of Ophthalmology, Afyonkarahisar Health Sciences University, Afyonkarahisar, Turkey

2Department of Ophthalmology, Afyonkarahisar State Hospital, Afyonkarahisar, Turkey

${ }^{3}$ Department of Pathology, Afyonkarahisar Health Sciences University, Afyonkarahisar, Turkey

${ }^{4}$ Department of Pathology, Afyonkarahisar State Hospital, Afyonkarahisar, Turkey

\begin{abstract}
Objectives: The aim of this study was to histopathologically compare patients with and without diabetes mellitus who underwent pterygium excision.

Methods: In this retrospective case-control study, 60 patients with a history of pterygium excision were divided into 2 groups: those with DM and those without DM. Histopathological findings (squamous metaplasia, dysplasia, inflammation, fibrinoid changes, and vascularization) were compared.

Results: The mean age of the 60 patients (females, 54.5\%) included in the study was $58.6 \pm 12.8$ years. The mean age was $53.7 \pm 13.7$ years in the patients with DM and $63.6 \pm 9.6$ years in the patients without DM. There were no significant differences in the excised pterygium tissues in terms of squamous metaplasia, dysplasia, fibrinoid changes, inflammation, or vascularization.

Conclusion: There was no histopathological difference in the pterygium tissue in patients with DM.

Keywords: Diabetes mellitus, inflammation, pterygium, vascularization.
\end{abstract}

\section{Introduction}

Pterygium, one of the most common surface ocular lesions, is a fibrovascular neoformation that is characterized by a triangular or wing-shaped overgrowth of abnormal conjunctiva on the cornea. Pterygium tissue demonstrates degenerative and hyperplastic changes, proliferative and inflammatory features, and it has a rich vasculature (I). Many histopathological characteristics of chronic inflammation are also observed in pterygium. The presence of chronic inflammation in pterygium is also confirmed by factors such as the presence of lymphocytic infiltration consisting particularly of $T$ lymphocytes, plasma cells and mastocytes, increments of newly-formed blood vessels and of fibroblasts, the presence of degenerative collagen fibers, and the presence of abnormal elastic fibers. Though it is a benign disease, pterygium can be considered malignant due to characteristic features of uncontrolled proliferation, migration, angiogenesis, and recurrence (2). Moreover, there are studies reporting a higher expression of genes related to cell proliferation and angiogenesis, such as proliferating cell nuclear antigen, mutant p53, mitogen-activated protein kinase signaling pathway, matrix metalloproteinases (MMPs) and vascular endothelial growth factor $A$ in pterygium tissue than in normal conjunctiva tissue (3-5).

Address for correspondence: Ozgur Erogul, MD. Afyonkarahisar Saglik Bilimleri Universitesi, Oftalmoloji Anabilim Dali, Afyonkarahisar, Turkey

Phone: +90 5070099074 E-mail: ozgur_erogul@hotmail.com

Submitted Date: January 06, 2020 Accepted Date: February 16, 2020 Available Online Date: July 29, 2020

${ }^{\oplus}$ Copyright 2020 by Beyoglu Eye Training and Research Hospital - Available online at www.beyoglueye.com OPEN ACCESS This work is licensed under a Creative Commons Attribution-NonCommercial 4.0 International License. 
Diabetes mellitus (DM), a known threat to health, is a prominent cause of chronic vascular disease and cancer, as well as hepatic and renal dysfunction. DM can induce systemic oxidative stress, which in turn can lead to associated complications. The inflammatory response is also impaired in diabetic patients (6). Type $2 \mathrm{DM}$ and cancer frequently coexist in the same individual and epidemiological evidence accumulated in the last decade has suggested that the link between these 2 conditions may be causal (7). In many studies, DM has been shown to cause squamous metaplasia, squamous dysplasia, fibrosis, neovascularization, and inflammation.

This study was a comparison of the histopathological findings of patients with and without type 2 DM who underwent pterygium excision.

\section{Methods}

Clinical records of patients who underwent pterygium excision in our eye clinic were retrospectively screened and the pathology samples of 60 patients were re-evaluated. Thirty patients with type $2 \mathrm{DM}$ and 30 without type 2 DM were compared in terms of histopathological findings (squamous metaplasia, dysplasia, inflammation, fibrinoid changes, and vascularization). The present study was approved by the Afyon Kocatepe University Clinical Research Ethics Committee and all procedures were performed in accordance with the tenets of the Declaration of Helsinki.

Pterygium tissues were histopathologically examined in terms of the degree of vascularization, inflammation intensity, and fibrinoid changes. This procedure was performed according to the criteria described by Džunić et al. (8) (Table I). The presence of metaplasia and dysplasia in the cells was histopathologically evaluated using the definitions provided by Chui et al. (9).

\section{Statistical Analysis}

Data analyses were performed using the PASW Statistics for Windows, Version 18.0 (SPSS Inc., Chicago, IL, USA) program. Descriptive statistics were expressed as mean, SD and number (percentage). Parametric variables were compared using the Student's t-test and non-parametric variables were compared using the Mann-Whitney $U$ test. Categorical variables were tested with a chi-square test. A p value of $<0.05$ was considered statistically significant.

\section{Results}

The present study included a total of 60 patients (30 with type 2 DM and 30 without type 2 DM) who underwent pterygium excision. The mean age of the entire study group $(n=60)$ was $58.6 \pm I 2.8$ years. The general characteristics of the patients with and without DM are presented in Table 2. The mean blood glucose level was $183 \pm 84.7 \mathrm{ng} / \mathrm{dL}$ in the patients with $\mathrm{DM}$ and $85 \pm \mathrm{II} \mathrm{ng} / \mathrm{dL}$ in the non-diabetic group. The mean glycosylated hemoglobin level was $7.3 \%$ in the patients with DM and the mean duration of DM was $1 \mathrm{I} .8 \mathrm{I} \pm 7.26$ years.

There were no significant differences in the excised pterygium tissues in terms of squamous metaplasia, dysplasia, fibrinoid changes, inflammation, or vascularization (Table 3).

\section{Discussion}

Histopathologically, pterygium is characterized by the centripetal growth of a cluster of altered limbal stem cells (LSCs), followed by squamous metaplastic and goblet cell

Table I. Criteria for histopathological examination of pterygium tissues (adapted from the study by Džunić et al. (8)

\begin{tabular}{|c|c|c|c|}
\hline Grade & Inflammation intensity & Degree of vascularization & Fibrinoid change \\
\hline 0 & No inflammatory infiltrate & $\begin{array}{l}\text { Vascularization of pterygium resembles } \\
\text { normal conjunctiva }\end{array}$ & No fibrinoid change \\
\hline I & $\begin{array}{l}\text { Sporadic, perivascular presence } \\
\text { of lymphocytes }\end{array}$ & $\begin{array}{l}\text { Presence of arteriole blood vessels } \\
\text { is dominant in the region of the } \\
\text { vascular stalk }\end{array}$ & Rare focal, perivascular fibrinoid changes \\
\hline 2 & $\begin{array}{l}\text { Multifocal chronic inflammatory } \\
\text { infiltrate (mostly lymphocytes) }\end{array}$ & $\begin{array}{l}\text { Presence of arterial blood vessels } \\
\text { in the center of pterygium }\end{array}$ & $\begin{array}{l}\text { A greater number of focal perivascular } \\
\text { changes }\end{array}$ \\
\hline 3 & $\begin{array}{l}\text { Multifocal chronic inflammatory } \\
\text { infiltrate (domination of plasmocytes) }\end{array}$ & $\begin{array}{l}\text { A stronger presence of capillary blood } \\
\text { vessels subepithelially and in the } \\
\text { advanced region }\end{array}$ & $\begin{array}{l}\text { A greater number of focal changes and } \\
\text { sporadically subepithelial }\end{array}$ \\
\hline 4 & Diffusive chronic inflammatory infiltrate & $\begin{array}{l}\text { More expressed presence of arteriole } \\
\text { blood vessels subepithelially and in } \\
\text { the advanced region. }\end{array}$ & $\begin{array}{l}\text { A greater number of focal and diffusively } \\
\text { subepithelial and/or massive change } \\
\text { in the progressive part }\end{array}$ \\
\hline
\end{tabular}


Table 2. General characteristics of the patients

\begin{tabular}{lccc} 
& $\begin{array}{c}\text { Total } \\
\mathbf{n}=\mathbf{6 0}\end{array}$ & $\begin{array}{c}\text { Patients with DM } \\
\mathbf{n = 3 0}\end{array}$ & $\begin{array}{c}\text { Patients without DM } \\
\mathbf{n}=\mathbf{3 0}\end{array}$ \\
\hline $\begin{array}{l}\text { Age, years, mean } \\
\text { Gender, n (\%) }\end{array}$ & $58.6 \pm 12.8$ & $63.6 \pm 9.6$ & $53.7 \pm 13.7$ \\
$\quad \begin{array}{l}\text { Male } \\
\text { Female }\end{array}$ & $28(46.6)$ & $12(40)$ & $16(53.4)$ \\
Blood glucose, ng/dL, mean & $32(53.4)$ & $18(60)$ & $14(46.6)$ \\
\end{tabular}

DM: Diabetes mellitus.

Table 3. Comparison of histopathological values

\begin{tabular}{|c|c|c|c|}
\hline & $\begin{array}{c}\text { Patients with DM } \\
\text { n=30 (\%) }\end{array}$ & $\begin{array}{c}\text { Patients without DM } \\
\qquad n=30(\%)\end{array}$ & $\mathbf{p}^{*}$ \\
\hline \multirow[t]{2}{*}{ Squamous metaplasia } & Grade I $n=22(36.7)$ & Grade I n=24 (40) & 0.381 \\
\hline & Grade $2 n=8(13.3)$ & Grade $2 \mathrm{n}=6(10)$ & \\
\hline \multirow[t]{2}{*}{ Squamous dysplasia } & Grade I n=5 (8.3) & Grade I n=6 (10) & 0.500 \\
\hline & Grade $2 \mathrm{n}=25(4 \mid .7)$ & Grade 2 n=24 (40) & \\
\hline \multirow[t]{3}{*}{ Vascularization } & Grade I n=3 (5) & Grade I n=4 (6.7) & 0.753 \\
\hline & Grade 2 n=2I (35) & Grade 2 n=22 (36.7) & \\
\hline & Grade $3 n=6(10)$ & Grade $3 n=4(6.7)$ & \\
\hline \multirow[t]{5}{*}{ Fibrinoid changes } & Grade $0 \mathrm{n}=1$ (I.7) & Grade $0 \mathrm{n}=\mathrm{I}(\mathrm{I} .7)$ & 0.924 \\
\hline & Grade I n=6 (10) & Grade I n=9 (15) & \\
\hline & Grade 2 n=9 (15) & Grade 2 n=8 (13.3) & \\
\hline & Grade $3 n=11(18.3)$ & Grade $3 n=10(16.7)$ & \\
\hline & Grade 4 n=3 (5) & Grade $4 \mathrm{n}=2$ (3.3) & \\
\hline \multirow[t]{5}{*}{ Inflammation intensity } & Grade $0 \mathrm{n}=2$ (3.3) & Grade $0 \mathrm{n}=0(0)$ & 0.181 \\
\hline & Grade I $n=\mid 3(2 \mid .7)$ & Grade I n=I7 (28.3) & \\
\hline & Grade $2 \mathrm{n}=10(16.7)$ & Grade $2 \mathrm{n}=11$ (18.3) & \\
\hline & Grade $3 n=5(8.3)$ & Grade $3 n=I$ (I.7) & \\
\hline & Grade $4 \mathrm{n}=0(0)$ & Grade $4 \mathrm{n}=\mathrm{I}(\mathrm{I} .7)$ & \\
\hline
\end{tabular}

*Chi-square test; DM: Diabetes mellitus.

hyperplastic epithelium, Bowman's membrane dissolution accompanied by abundant active fibroblasts, a proliferative stroma with inflammation, neovascularization, and extracellular matrix. Previous studies have indicated that pterygium is associated with numerous risk factors, including ultraviolet radiation (UVR); viral infection; hereditary factors; immunological factors; aseptic inflammation; environmental irritation from wind, dust, or smoke; trauma; and ocular dryness. Recently, increased levels of the transcription factors CAMP response element-binding protein, cytochrome P450 IAI protein, phospholipase $\mathrm{D}$, and aquaporin $\mathrm{I}$ and 3 have been suggested as risk factors for pterygium development (10).

A high blood sugar level is an important factor in the development of certain types of cancer due to the induction of cellular dysplasia, which in turn may trigger an inflammatory reaction (7). Although pterygium is benign, it can be considered malignant as it may recur after treatment and due to the use of antineoplastic drugs in its treatment (9). Previous studies have investigated DM as a risk factor for pterygium (II); however, no relationship between pterygium and DM has yet been reported. To the best of our knowledge, this is the first study to investigate the effect of DM on pterygium 
through histopathological evaluation. Inflammatory pathways have been considered as an underlying pathogenic factor for DM. The generation of free oxygen radicals and oxidative stress has also been suggested as the root cause underlying the development of type 2 DM (I2).

Pterygium is a multifactorial condition that is mainly associated with aging and exposure to UVR. Because diabetes accelerates the aging process, it may contribute to the development of diseases typical of aging and that ocular aging may lead to the progression of pterygium (I3).

There are several possible mechanisms by which DM could promote the progression of pterygium. First, DM induces the deposition of various degeneration products that may contribute to the progression of pterygium, including the formation of advanced glycation end products (AGEs). Kaji et al. (14) recently demonstrated the immunolocalization of AGEs in human pterygium versus little or no immunolocalization of AGEs in normal conjunctival tissue without pterygium. AGEs accumulate naturally with aging or in the presence of a high glucose concentration in patients with DM. They may accumulate in fibrous tissue in the nasal and temporal conjunctivae, resulting in the progression of pterygium.

Second, diabetic microvascular damage and differentiation of the conjunctival tissue may be a leading cause of pterygium. The prevalence of diabetic microvascular complications is higher in patients with poor glycemic control or a longer duration of diabetes $(15,16)$. Most of the vessels located on the nasal or temporal conjunctiva supply blood to the extraocular muscles and limbal cornea. Diabetic microvascular disease affects small vessels, such as those supplying the retina, nerves, and kidneys, and may also affect the conjunctival vessels (I7). Ischemia due to vascular damage includes perivascular fibrosis and the accumulation of macrophages and lymphocytes (18). Pericytes and perivascular fibroblasts are the primary source of perivascular fibrosis (19). Fibrosis of the nasal or temporal conjunctiva associated with microvascular damage may be involved in the progression of pterygium. In another study, an increase in vascularization was determined in the pterygium tissue (8). Furthermore, the level of vascular growth factors related to the formation of diabetic retinopathy, which is one of the vascular complications of DM, were found to be elevated in pterygium tissue (20). Similarly, Cheung et al. (2I) identified the presence of microvascular changes in the conjunctival microcirculation of type 2 DM patients. An increase in the degree of vascularization in diabetic patients was expected in our study; however, there was no significant difference between diabetic and non-diabetic patients.

Third, dryness of the eyes induced by diabetes may contribute to the progression of pterygium. The tear film has been reported to be unstable in patients with DM (22), and they have a higher prevalence of dry eye syndrome compared with non-diabetics (22-26). Dry eyes occur in diabetes because of decreased corneal sensitivity, neuropathy involving the lacrimal glands, and loss of goblet cells (27). The average blink rate is also lower in patients with diabetes than in control subjects (28). Accordingly, pterygium probably develops secondary to inflammation caused by friction between the bulbar and palpebral conjunctivae due to dryness. The levels of inflammatory cytokines in tear fluid are increased by delayed clearance of tears (29), so obliteration of the tear meniscus and delayed tear clearance could also aggravate superficial ocular inflammation $(30,31)$, leading to pinguecula, and finally pterygium. Together, these findings suggest that diabetes-related dryness of the eyes may stimulate the production of inflammatory molecules, which may induce pinguecula in patients with DM.

Kormanovski et al. (32) investigated the oxidant/antioxidant state of primary and recurrent pterygium tissue and reported that compared with a control group, the primary pterygium group had increased levels of nitric oxide and total antioxidant status and a decreasing tendency in the level of all antioxidant enzymes; that is, an increase in non-enzymatic antioxidant activity. Accordingly, considering the effects of oxidative stress and inflammatory pathways in DM and pterygium, we compared inflammation intensity of the pterygium tissues between patients with and without DM and observed no significant difference.

Fibrinoid degeneration may be observed in pterygium tissue in the perivascular areas (8). It may also be observed in other tissues in DM patients $(33,34)$. It has been shown in literature reports that DM causes chronic inflammation leading to pancreatic fibrosis. Accordingly, in the present study, we expected an increase in fibrinoid degeneration in the pterygium tissues of DM patients, but no significant difference was observed between the groups.

As previously mentioned, although pterygium is considered a benign lesion, it displays malignant characteristics, such as a high recurrence rate after surgical removal, the need for antineoplastic agents in treatment, and coexistence with secondary premalignant lesions (9). In the study by Sun et al. (35), it was reported that ocular surface squamous neoplasia, which was classified as mild dysplasia, moderate dysplasia, severe dysplasia, and carcinoma in-situ, was determined in 14 (13.3\%) of 105 surgically removed pterygium tissue samples. In another study, Chui et al. (9) investigated the rate of concurrent ocular surface diseases in patients with pterygium and reported mild to severe epithelial dysplasia at rate of $5 \%$. In the present study, no dysplasia was observed in the pterygium tissue cells of DM patients. Moreover, no significant difference was observed between the diabetic and 
non-diabetic patients. With regard to squamous metaplasia, several studies in the literature have shown that DM can lead to squamous metaplasia in the conjunctival epithelium. In our study, however, the degree of squamous metaplasia in the pterygium tissue was not significantly different between diabetic and non-diabetic patients.

Pterygium is regarded as an ophthalmoheliose triggered by chronic UV damage. As UVR results in the induction of diverse biological effects, it provides a good explanation for the pathogenesis of pterygium. Chronic UVR specifically damages the nasal limbus as peripheral light focuses in that part of the eye. There may be no clinical indication of abnormality, but it may be effectively detected by UV fluorescence photography (36). It is well established that UV-altered limbal basal epithelial cells are the first step in the initiation of pterygium; however, the precise underlying molecular mechanism remains to be elucidated. UVR is known to be mutagenic, and gene mutation has been associated with the formation of pterygium cells. Clarifying the mechanism through which UVR alters the LSCs is likely to predict the biological behavior of these altered LSCs in pterygium and help to devise appropriate surgical and medical therapeutic strategies. Similarly, UVR may alter or activate fibroblasts located in the nasal limbal connective tissue, as these cells receive increased levels of UVR compared with other parts of limbus due to limbal light focusing. Although UVR may explain the abnormal biological behavior of fibroblasts in pterygia, the origin of pterygium fibroblasts remains unknown. Further studies aiming to explain the mechanism by which LSCs and fibroblasts evolve into pterygium cells and pterygium fibroblasts are required. Based on the common histopathological changes, including inflammation, neovascularization, elastotic degeneration, Bowman's membrane degradation, and fibrous hyperplasia, it is hypothesized that inflammatory cytokines, angiogenic factors, fibrogenic factors and tissue proteolytic enzymes may be involved in the development of pterygium. Previous studies have demonstrated increased levels of multiple growth factors, pro-inflammatory cytokines, and MMPs in pterygium (37-39). The elevated expression of these effectors in pterygium has been attributed to UVR, as they were demonstrated to be UVR-inducible in pterygium-derived cells in culture or explants in vitro. However, understanding of the detailed underlying mechanisms is limited.

jiao et al. (40) found that outdoor time equal to or more than 4 hours per day during daylight had a positive association with pterygium; the longer the subjects stayed outside, the higher the prevalence was. Consequently, cumulative exposure to UVR increases the prevalence of pterygium. In this study it was also proved that using hat and/or sunglasses was protective for pterygium, which was consistent with the conclusions of the Barbados Eye Study $(4 I, 42)$. The mecha- nism behind this phenomenon could be due to blocking ocular UVR exposure and other environmental factors, such as dust (43).

In the present study, the insignificant differences in the parameters investigated may be linked to multitude of limiting factors. First, it could be due to an insufficient sample size. Second, pterygium duration before excision may have a crucial role with respect to the tissue metaplasia processes as well as other related tissue modifications, so a long-term longitudinal study is needed. The subjectivity of pterygium conditions renders it quite difficult to detect and to evaluate histopathologically. Further studies are needed to clarify the relationship between pterygium and duration in patients with DM.

In conclusion, since severe pterygium can result in visual impairment and blindness, it is important to take some preventive measures to diminish the prevalence of pterygium, such as suggesting that people wear a hat and/or sunglasses whenever they are outside in the sunshine, educating outdoor workers to raise their awareness for pterygium, and providing surgery service when pterygium is diagnosed. In contrast to various studies in the literature, in our study DM was not observed to be a risk factor for pterygium development; No significant histopathologic differences in the pterygium tissues of diabetic patients were observed.

\section{Disclosures}

Ethics Committee Approval: The Ethics Committee of Afyon Kocatepe University provided the ethics committee approval for this study (03.02.2017-2017/37).

Peer-review: Externally peer-reviewed.

Conflict of Interest: None declared.

Authorship Contributions: Involved in design and conduct of the study (OE, LEE, NLS, FC, MD, HHG); preparation and review of the study (OE, LEE, NLS, FC, MD, HHG); data collection (OE, LEE, NLS, FC, MD, HHG); and statistical analysis (OE, LEE, NLS, FC, MD, HHG).

\section{References}

I. Kase S, Takahashi S, Sato I, Nakanishi K, Yoshida K, Ohno S. Expression of p27(KIPI) and cyclin DI, and cell proliferation in human pterygium. Br J Ophthalmol 2007;91:958-61. [CrossRef]

2. Bradley JC, Yang W, Bradley RH, Reid TW, Schwab IR. The science of pterygia. Br J Ophthalmol 20 10;94:8I5-20. [CrossRef]

3. Chowers I, Pe'er J, Zamir E, Livni N, Ilsar M, Frucht-Pery J. Proliferative activity and $\mathrm{p} 53$ expression in primary and recurrent pterygia. Ophthalmology 2001;108:985-8. [CrossRef]

4. Yang SF, Lin CY, Yang PY, Chao SC, Ye YZ, Hu DN. Increased expression of gelatinase (MMP-2 and MMP-9) in pterygia and pterygium fibroblasts with disease progression and activation of protein kinase C. Invest Ophthalmol Vis Sci 2009;50:4588-96.

5. Gharaee H, Shayegan MR, Khakzad MR, Kianoush S, Varasteh 
AR, Sankian M, et al. The expression of vascular endothelial growth factor in pterygium tissue of atopic patients. Int Ophthalmol 2014;34: I 175-8I. [CrossRef]

6. Alba-Loureiro TC, Munhoz CD, Martins JO, Cerchiaro GA, Scavone C, Curi R, et al. Neutrophil function and metabolism in individuals with diabetes mellitus. Braz J Med Biol Res 2007;40:1037-44. [CrossRef]

7. Onitilo AA, Engel JM, Glurich I, Stankowski RV, Williams GM, Doi SA. Diabetes and cancer I: risk, survival, and implications for screening. Cancer Causes Control 2012;23:967-8I. [CrossRef]

8. Džunić B, Jovanović P, Veselinović D, Petrović A, Stefanović I, Kovačević I. Analysis of pathohistological characteristics of pterygium. Bosn J Basic Med Sci 2010;10:307-13. [CrossRef]

9. Chui J, Coroneo MT, Tat LT, Crouch R, Wakefield D, Di Girolamo N. Ophthalmic pterygium: a stem cell disorder with premalignant features. Am J Pathol 20I I;178:8I7-27. [CrossRef]

10. Chui J, Di Girolamo N, Wakefield D, Coroneo MT. The pathogenesis of pterygium: current concepts and their therapeutic implications. Ocul Surf 2008;6:24-43. [CrossRef]

II. Asokan R, Venkatasubbu RS, Velumuri L, Lingam V, George R. Prevalence and associated factors for pterygium and pinguecula in a South Indian population. Ophthalmic Physiol Opt 2012;32:39-44. [CrossRef]

12. Lontchi-Yimagou E, Sobngwi E, Matsha TE, Kengne AP. Diabetes mellitus and inflammation. Curr Diab Rep 2013;13:435-44.

13. Mimura T, Obata H, Usui T, Mori M, Yamagami S, Funatsu H, et al. Pinguecula and diabetes mellitus. Cornea 20I2;3I:264-8.

14. Kaji Y, Oshika T, Amano S, Okamoto F, Koito W, Horiuchi S. Immunohistochemical localization of advanced glycation end products in pinguecula. Graefes Arch Clin Exp Ophthalmol 2006;244:104-8. [CrossRef]

15. Shera AS, Jawad F, Maqsood A, Jamal S, Azfar M, Ahmed U. Prevalence of chronic complications and associated factors in type 2 diabetes. J Pak Med Assoc 2004;54:54-9.

16. Nepp J, Abela C, Polzer I, Derbolav A, Wedrich A. Is there a correlation between the severity of diabetic retinopathy and keratoconjunctivitis sicca?. Cornea 2000;19:487-91. [CrossRef]

17. Mimura T, Usui T, Yamagami S, Funatsu H, Noma H, Honda N, et al. Recent causes of subconjunctival hemorrhage. Ophthalmologica 2010;224:133-7. [CrossRef]

18. Vinten-Johansen J, et al. Sequential patterns of chemokine- and chemokine receptor-synthesis following vessel Wall injury in porcine coronary arteries. Atherosclerosis. 2007;192:75-84

19. Chevalier RL, Forbes MS, Thornhill BA. Ureteral obstruction as a model of renal interstitial fibrosis and obstructive nephropathy. Kidney Int 2009; 75: I I45-52. [CrossRef]

20. Marcovich AL, Morad Y, Sandbank J, Huszar M, Rosner M, Pollack $A$, et al. Angiogenesis in pterygium: morphometric and immunohistochemical study. Curr Eye Res 2002;25:17-22. [CrossRef]

21. Cheung AT, Ramanujam S, Greer DA, Kumagai LF, Aoki TT. Microvascular abnormalities in the bulbar conjunctiva of patients with type 2 diabetes mellitus. Endocr Pract 2001;7:358-63.

22. Dogru M, Katakami C, Inoue M. Tear function and ocular surface changes in noninsulin-dependent diabetes mellitus. Ophthalmology 200 I; 108:586-92. [CrossRef]

23. Seifart U, Strempel I. Trockenes Auge und Diabetes mellitus [The dry eye and diabetes mellitus]. Ophthalmologe 1994;91:235-9.

24. Goebbels $M$. Tear secretion and tear film function in insulin dependent diabetics. Br J Ophthalmol 2000;84: I9-2I. [CrossRef]

25. Kaiserman I, Kaiserman N, Nakar S, Vinker S. Dry eye in diabetic patients. Am J Ophthalmol 2005; 139:498-503. [CrossRef]

26. Dogru M, Stern ME, Smith JA, Foulks GN, Lemp MA, Tsubota $K$. Changing trends in the definition and diagnosis of dry eyes. Am J Ophthalmol 2005; |40:507-8. [CrossRef]

27. Rahman A, Yahya K, Ahmed T, Sharif-Ul-Hasan K. Diagnostic value of tear films tests in type 2 diabetes. J Pak Med Assoc 2007;57:577-8I.

28. Inoue K, Okugawa K, Amano S, Oshika T, Takamura E, Egami F, et al. Blinking and superficial punctate keratopathy in patients with diabetes mellitus. Eye (Lond) 2005; 19:4I8-2I. [CrossRef]

29. Afonso AA, Sobrin L, Monroy DC, Selzer M, Lokeshwar B, Pflugfelder SC. Tear fluid gelatinase B activity correlates with IL-Ialpha concentration and fluorescein clearance in ocular rosacea. Invest Ophthalmol Vis Sci 1999;40:2506-12.

30. Prabhasawat $\mathrm{P}$, Tseng SC. Frequent association of delayed tear clearance in ocular irritation. Br J Ophthalmol 1998;82:666-75.

31. Di Pascuale MA, Espana EM, Kawakita T, Tseng SC. Clinical characteristics of conjunctivochalasis with or without aqueous tear deficiency. Br J Ophthalmol. 2004;88:388-92. [CrossRef]

32. Kormanovski A, Parra F, Jarillo-Luna A, Lara-Padilla E, Pacheco-Yépez J, Campos-Rodriguez R. Oxidant/antioxidant state in tissue of prymary and recurrent pterygium. BMC Ophthalmol 20|4; |4: |49. [CrossRef]

33. Jagadapillai R, Rane MJ, Lin X, Roberts AM, Hoyle GW, Cai L, et al. Diabetic Microvascular Disease and Pulmonary Fibrosis: The Contribution of Platelets and Systemic Inflammation. Int J Mol Sci 2016;17:1853. [CrossRef]

34. Jarmuzek P, Wielgos M, Bomba-Opon D. Placental pathologic changes in gestational diabetes mellitus. Neuro Endocrinol Lett 2015;36:101-5.

35. Sun LL, Warrier S, Beckingsale P. Pterygium and Rate of Dysplasia in Surgical Specimens. J Clinic Experiment Ophthalmol 201 1;2:166. [CrossRef]

36. Ooi JL, Sharma NS, Papalkar D, Sharma S, Oakey M, Dawes P, et al. Ultraviolet fluorescence photography to detect early sun damage in the eyes of school-aged children. Am J Ophthalmol 2006; | 41:294-8. [CrossRef]

37. Dushku N, John MK, Schultz GS, Reid TW. Pterygia pathogenesis: corneal invasion by matrix metalloproteinase expressing altered limbal epithelial basal cells. Arch Ophthalmol 200 I; I 19:695-706. [CrossRef] 
38. Di Girolamo N, Kumar RK, Coroneo MT, Wakefield D. UVB-mediated induction of interleukin- 6 and -8 in pterygia and cultured human pterygium epithelial cells. Invest Ophthalmol Vis Sci 2002;43:3430-7.

39. Kria L, Ohira A, Amemiya T. Immunohistochemical local $\neg i z a-$ tion of basic fibroblast growth factor, platelet derived growth factor, transforming growth factor beta and tumor necrosis factor - alpha in the pterygium. Acta Histochem 1996;98:195-20I.

40. Jiao W, Zhou C, Wang T, Yang S, Bi H, Liu L, et al. Prevalence and risk factors for pterygium in rural older adults in Shan- dong Province of China: a cross-sectional study. Biomed Res Int 20।4;20। 4:658648. [CrossRef]

4I. Luthra R, Nemesure BB, Wu SY, Xie SH, Leske MC; Barbados Eye Studies Group. Frequency and risk factors for pterygium in the Barbados Eye Study. Arch Ophthalmol 200 I; I 9:1827-32.

42. Tan CS, Lim TH, Koh WP, Liew GC, Hoh ST, Tan CC, et al. Epidemiology of pterygium on a tropical island in the Riau Archipelago. Eye (Lond) 2006;20:908-12. [CrossRef]

43. Detels R, Dhir SP. Pterygium: a geographical study. Arch Ophthalmol 1967;78:485-9I. [CrossRef] 